\title{
DEKONSTRUKSI ASAS LEGALITAS DALAM HUKUM PIDANA
}

\author{
Ateng Sudibyo ${ }^{1}$ \\ Aji Halim Rahman ${ }^{2}$
}

\begin{abstract}
ABSTRAK
Asas legalitas sering dilihat sebagai ketentuan yang secara absolut dianggap benar sehingga secara formil pasti telah mewakili rasa keadilan masyarakat. Oleh sebab itu, ketentuan-ketentuan dalam undang-undang harus ditegakkan bagaimanapun caranya dan mesti diperlakukan sebagai representasi dari nilainilai keadilan. Konsekuensi dari pola pikir dan paradigma seperti ini tentu saja adalah persepsi yang berlebihan dengan menganggap bahwa hukum adalah undang-undang dan undang-undang sama dengan hukum. Paradigma formalistik dalam melihat hukum ini telah berakibat semakin sulitnya menemukan keadilan sejati. Yang ada adalah keadilan yang formal, sempit dan kaku, yakni keadilan yang tidak mewakili semua hak dan kepentingan, baik hak korban, pelaku, negara, dan masyarakat. Oleh karena itu muncul berbagai wacana untuk menggali Asas Legalitas yang dapat mewakili norma hukum yang hidup dan berkembang dalam masyarakat.

Metode penelitian yang digunakan adalah penelitian hukum normatif yang bersifat deskriptif analisis, pengumpulan data dilakukan dengan menggunakan data primer dan data sekunder berupa bahan hukum primer, sekunder dan tertier sebagai data utama. Setelah data sekunder dan primer terkumpul, kemudian diadakan analisis secara kualitatif

Berdasarkan hasil analisis data, disimpulkan bahwa kedudukan Asas legalitas formil diterapkan untuk mencegah kesewenang-wenangan penguasa terhadap orang yang tidak bersalah. Sedangkan asas legalitas materiil untuk mengakomodir hukum tidak tertulis yang masih berlaku di masyarakat. Dekonstruksi asas legalitas dalam hukum pidana dilakukan dengan menggali dan memasukkan nilai-nilai hukum adat agar mampu menyelesaikan penyimpangan kejahatan. Penyimpangan kejahatan dalam artian bukan tergantung pada ketetapan hukum yang ditetapkan dalam hukum pidana secara tertulis, namun menekankan pula pada hukum tidak tertulis.
\end{abstract}

\section{Kata Kunci: Dekonstruksi, Asas Legalitas, Hukum Pidana}

\footnotetext{
${ }^{1}$ Guru SMPN Satap Cengal Maja Majalengka, email : atengsudibyo099@gmail.com

2 Dosen FH Universitas Majalengka, email : Ajihalimrahman09051995@gmail.com
} 
PRESUMPTION of LAW

Fakultas Hukum Universitas Majalengka

Volume 3 Nomor 1 April 2021

\section{A. Latar Belakang}

Asas legalitas yang dikenal dalam hukum pidana di Indonesia muncul dari ruang lingkup sosiologis yang mengagungkan doktrin perlindungan rakyat dari perlakuan sewenang-wenang kekuasaan. $^{3}$ Sebelum datang abad pencerahan kekuasan dapat menghukum orang meski tanpa ada peraturan terlebih dahulu, saat itu selera kekuasanlah yang paling berhak menentukan apakah perbuatan dapat di hukum atau tidak. Untuk menangkalnya, hadirlah asas legalitas yang merupakan instrumen penting perlindungan kemerdekaan individu saat berhadapan dengan negara.

Negara Indonesia dalam Hukum positif nya mengenal asas legalitas dalam Pasal 1 ayat (1) KUHP, yang menyatakan bahwa setiap perbuatan yang disebut sebagai perbuatan/tindak pidana harus dirumuskan dalam undangundang yang diadakan terlebih dahulu yang menetapkan dalam rumusan yang jelas tentang perbuatan-perbuatan dimaksud. Asas legalitas dalam hukum pidana dirumuskan dalam beberapa versi adagium, seperti nullum delictum nulla poena sine praevea lege poenali (tiada delik, tiada pidana, tanpa undangundang pidana terlebih pidana, tanpa undang-undang pidana terlebih dahulu). Suatu perbuatan tidak dapat dikualifikasikan sebagai tindak pidana jika tidak dinyatakan sebagai perbuatan pidana oleh undang-undang pidana. Perbuatan pidana yang di larang oleh undang-undang pidana dikenal sebagai mala prohibita. Mala prohibita merupakan perbuatan perbuatan yang strafbaar (dapat dipidana).

Perbuatan pidana yang belum atau tidak dilarang oleh undang-undang pidana dikenal sebagai crimina extra ordinaria. ${ }^{4}$ Terhadap crimina extra ordinaria tidak dapat dilakukan penuntutan, karena belum dinyatakan sebagai mala prohibita, walaupun menimbulkan kerugian yang luar biasa bagi korban dan/atau masyarakat. Di antara crimina extra ordinaria tersebut terdapat perbuatan yang sangat terkenal yaitu crimina stellionatus (yang artinya: perbuatan jahat atau durjana). ${ }^{5}$ Crimina extra ordinaria merupakan perbuatan yang strafwaardig (patut dipidana) tetapi bukan strafbaar, karena tidak dilarang oleh undang-undang pidana.

Para ahli hukum pidana, pada umumnya sepakat dengan adanya 3 (tiga) makna asas legalitas, yaitu: ${ }^{6}$ pertama, tidak ada perbuatan yang dilarang dan diancam dengan pidana kalau hal itu belum dinyatakan terlebih dahulu dalam suatu aturan undang-undang; kedua, untuk menentukan adanya perbuatan pidana tidak boleh digunakan analogi (kiyas); dan ketiga, aturan-aturan hukum pidana tidak berlaku surut.

Tiga makna tersebut memberikan beberapa implikasi. Pertama, larangan menggunakan analogi (prinsip non-analogi), dan kedua, keharusan menggunakan undang-undang pidana yang berlaku pada saat perbuatan

3 Deddy Ismatullah, Ilmu Negara dalam Multi Perspektif Kekuasaan, Masyarakat, Hukum, dan Agama, Pustaka setia, Bandung, 2007, hlm. 67

${ }^{4}$ Moeljatno, Asas-Asas Hukum Pidana, Rineka Cipta, Jakarta, 2000, hlm. 24

${ }^{5}$ Ibid

${ }^{6}$ Ibid., hlm. 25 
PRESUMPTION of LAW

Fakultas Hukum Universitas Majalengka

Volume 3 Nomor 1 April 2021

dilakukan (lex temporis delicti atau existing criminal laws). Dilarang memberlakukan undang-undang pidana secara retroaktif (prinsip nonretroaktif). Implikasi tersebut merupakan konsekuensi logis dari ide dasar (basic ideas) asas legalitas, yaitu melindungi individu dengan cara membatasi dari kekuasaan penguasa (termasuk kewenangan hakim), yang mana pembatasan ini menggunakan instrumen undang-undang pidana.

Ide dasar di atas, secara substansial berimplikasi pada fungsi asas legalitas. Asas legalitas hanya melaksanakan 2 (dua) fungsi, yaitu fungsi perlindungan, melindungi warga negara dari kesewenang-wenangan kekuasaan penguasa dan/atau kewenangan hakim dan fungsi pembatasan, membatasi kekuasaan penguasa dan/atau kewenangan hakim. Fungsi perlindungan ternyata hanya diberikan kepada para pelaku. Pelaku tidak akan dituntut selama perbuatan mereka tidak dilarang oleh undang-undang pidana, walaupun perbuatan tersebut menimbulkan kerugian yang luar biasa bagi korban dan/atau masyarakat. Fungsi pembatasan juga hanya untuk kepentingan pelaku, karena pemerintah tidak boleh menuntut seseorang yang perbuatannya tidak dilarang oleh undang-undang pidana, walaupun perbuatan tersebut menimbulkan kerugian luar biasa bagi korban dan/ atau masyarakat ${ }^{7}$. Sebagai konsekuensinya, sebuah perbuatan yang menurut pandangan masyarakat dianggap sebagai perbuatan tercela karena melanggar nilai-nilai hukum yang hidup dalam masyarakat tidak dapat dipidana karena tidak diatur secara tertulis dalam undang-undang. ${ }^{8}$ Dengan bahasa yang lain, Deni Setyo Bagus Yuherawan menyatakan bahwa sangat tidak masuk akal membebaskan orang yang telah melakukan kejahatan hanya karena kejahatan itu tidak dilarang oleh undang-undang pidana. Hal ini karena setiap perilaku kejahatan harus ada pertanggungjawaban pidananya. $^{9}$ Pertanggungjawaban tersebut hakikatnya merupakan upaya untuk mengembalikan keadaan menjadi baik seperti semula dan mewujudkan keadilan. Oleh karenanya sekecil apapun kejahatan harus ada pertanggungjawabannya.

Kondisi Asas Legalitas beserta segala konsekuensinya tersebut, telah merangsang munculnya beberapa kritik dan wacana pembaharuan dari para ahli hukum. Salah seorang dari mereka, Deni Setyo Bagus, menganggap sudah waktunya menumbuhkembangkan ide dekonstruktif terhadap Asas Legalitas dengan paradigma yang baru. Ia berargumentasi bahwa Asas Legalitas telah memperlakukan pelaku dan korban secara tidak proporsional. Asas legalitas hanya mengakomodasi kepentingan serta menjunjung tinggi hak asasi pelaku

${ }^{7}$ Deni SB Yuherawan, Kritik Ideologis Terhadap Dasar Kefilsafatan Asas Legalitas Dalam Hukum Pidana, Jurnal Dinamika Hukum Vol. 12 No. 2 Mei 2012, hlm 222

${ }^{8}$ I Dewa Made Suartha, "Pergeseran Asas Legalitas Formal Ke Formal dan Material dalam Pembaharuan Hukum Pidana Nasional", Fakultas Hukum Universitas Udayana Yustisia. Vol. 4 No. 1 Januari - April 2015 hlm. 139-140.

${ }^{9}$ Deni Setyo Bagus Yuherawan, Dekonstruksi Asas Legalitas Hukum Pidana; Sejarah Asas Legalitas dan gagasan Pembaharuan Filosofis Hukum Pidana, Setara Press, Malang, 2014, hlm. 7. 
PRESUMPTION of LAW

Fakultas Hukum Universitas Majalengka

Volume 3 Nomor 1 April 2021

dengan mengorbankan kepentingan dan hak asasi korban, yang sering kali berjumlah jauh lebih banyak dari pelaku. ${ }^{10}$

Asas legalitas sering dilihat sebagai ketentuan yang secara absolut dianggap benar sehingga secara formil pasti telah mewakili rasa keadilan masyarakat. Oleh sebab itu maka ketentuan-ketentuan dalam undang-undang harus ditegakkan bagaimanapun caranya dan mesti diperlakukan sebagai representasi dari nilai-nilai keadilan. Konsekuensi dari pola pikir dan paradigma seperti ini tentu saja adalah persepsi yang berlebihan dengan menganggap bahwa hukum adalah undang-undang dan undang-undang sama dengan hukum. Paradigma formalistik dalam melihat hukum ini telah berakibat semakin sulitnya menemukan keadilan sejati. Yang ada adalah keadilan yang formal, sempit dan kaku, yakni keadilan yang tidak mewakili semua hak dan kepentingan, baik hak korban, pelaku, negara, dan masyarakat. Oleh karena itu muncul berbagai wacana untuk menggali Asas Legalitas yang dapat mewakili norma hukum yang hidup dan berkembang dalam masyarakat. Dalam rangka memperkuat fungsi Asas Legalitas untuk mewujudkan keadilan hukum, menurut Sri Rahayu, bahwa penentuan tindak pidana harus didasarkan tidak hanya pada Asas Legalitas Formal melainkan juga pada Asas Legalitas Material. ${ }^{11}$ Senada dengan Rahayu, I Dewa Made Suartha berpendapat bahwa salah satu upaya pembaharuan hukum pidana dapat dilakukan dengan cara berpindah dari paradigma Asas Legalitas formal kepada Asas Legalitas formal dan material. ${ }^{12}$

Pemikiran yang sama disampaikan Barda Nawawi Arif mengkritisi ketentuan Asas Legalitas hukum pidana sebagaimana tercantum dalam KUHP Pasal 1 ayat (1). Menurutnya, dengan adanya ketentuan Pasal 1 ayat (1) KUHP, seolah-olah hukum pidana tidak tertulis yang hidup dalam masyarakat sengaja ditidurkan atau dimatikan. Ditidurkannya hukum pidana tidak tertulis pada jaman penjajahan bisa dimaklumi, karena memang sesuai dengan politik hukum Belanda saat itu. Namun akan sangat dirasakan janggal apabila kebijakan itu diteruskan setelah kemerdekaan. Dengan adanya asas legalitas formal, hukum tidak tertulis/hukum yang hidup menjadi tidak tergali dan terungkap secara utuh ke permukaan, khususnya dalam praktek peradilan pidana. $^{13}$

Asas legalitas sebagaimana yang termanifestasi dalam KUHP saat ini merupakan selera kultural Belanda, di mana kerangka pikir yang membawa paham individualism dan liberalism. Ringkasnya, asas legalitas tidak saja menjadi acuan menestapakan perbuatan tercela dengan pelbagi sanksi, akan tetapi asas legalitas telah melanggengkan sistem dominasi praktik kultural dengan pertukaran cara berhukum yang sama sekali tidak berangkat dari kultur

${ }^{10}$ Ibid, hlm 7

11 Tongat, Dasar-Dasar Hukum Pidana Indonesia dalam Perspektif Pembaharuan, UMM Press, Malang: 2012, hlm. 53-54.

12 I Dewa Made Suartha, "Pergeseran Asas ...Loc.Cit

13 Barda Nawawi Arief, Beberapa Aspek penegakan dan Pengembangan Hukum Pidana, PT. Citra Aditya Bakti, Bandung:2011, hlm. 122-123. 
PRESUMPTION of LAW

Fakultas Hukum Universitas Majalengka

Volume 3 Nomor 1 April 2021

bangsa Indonesia yang pemaaf, toleran, plural, kekeluargaan, bernurani, religius atau yang lebih berarti adalah jiwa Pancasila.

Berangkat dari paham individualistik, tidak heran KUHP yang berlaku saat ini hanya mengakui asas kepastian hukum, mengingat rasionalitas teks secara tertulis menjadi domain utama dalam menentukan salah-benar suatu perbuatan pidana. Dalam pengertian yang berbeda, hanya hukum pidana tertulis saja yang dapat menentukan mana perbuatan jahat dan tidak jahat. Secara filosofis KUHP saat ini menggenggam asas legalitas dalam pengertian formal, aspek materiel menjadi sesuatu yang tidak terbahas. Konsekuensi dari itu semua, hukum pidana tidak tertulis 'ditidurkan' dan 'dimatikan' oleh asas legalitas di dalam KUHP.

Berdasarkan uraian tersebut ternyata ada masalah yang menarik untuk dikaji berkaitan dengan masalah asas legalitas dalam hukum pidana yang dituangkan dalam judul Dekonstruksi Asas Legalitas Dalam Hukum Pidana

\section{B. Identifikasi Masalah}

Berkaitan dengan uraian diatas, maka perumusan masalah dalam jurnal ini adalah

1. Bagaimanakah kedudukan asas legalitas dalam hukum pidana Indonesia?

2. Bagaimanakah konsep dekonstruksi asas legalitas dalam hukum pidana nasional?

\section{Tujuan Penelitian}

Berdasarkan Identifikasi Masalah di atas, maka tujuan yang akan dicapai dalam penelitian ini adalah sebagai berikut :

1. Untuk mengetahui dan menganalisis kedudukan asas legalitas dalam hukum pidana Indonesia

2. Untuk mengetahui dan menganalisis konsep dekonstruksi asas legalitas dalam hukum pidana nasional

\section{Kerangka Pemikiran}

Kerangka pemikiran (berpikir) merupakan model konseptual tentang bagaimana teori berhubungan dengan berbagai faktor yang telah diidentifikasi sebagai masalah yang penting. Kerangka berfikir yang baik akan menjelaskan secara teoritis pertautan antar variabel yang akan diteliti. Oleh karena itu pada setiap penyusunan paradigma penelitian harus didasarkan pada kerangka berfikir dengan pemikiran-pemikiran teoritis

Sehubungan dengan permasalahan yang telah diuraikan di atas, maka kerangka pemikiran penelitian ini menggunakan teori vom psychologischen zwang dari Von Feurbach. Teori ini menganjurkan supaya dalam menentukan perbuatan-perbuatan yang dilarang di dalam peraturan bukan saja tentang macamnya perbuatan yang harus dituliskan dengan jelas, tetapi juga tentang macamnya pidana yang diancamkan. Dengan cara demikian ini, maka oleh orang yang akan melakukan perbuatan yang dilarang tadi lebih dahulu telah diketahui pidana apa yang akan dijatuhkan kepadanya jika nanti perbuatan itu 
PRESUMPTION of LAW

Fakultas Hukum Universitas Majalengka

Volume 3 Nomor 1 April 2021

dilakukan. Dengan demikian dalam batinnya, dalam psychennya, lalu diadakan tem atau tekanan untuk tidak berbuat, dan kalau sampai melakukan perbuatan tadi, maka jika dijatuhi pidana kepadanya bisa dipandang sebagai sudah disetujuainya sendiri. ${ }^{14}$ Jadi pendirian Von Feurbach mengenai pidana ialah pendirian yang tergolong absolud (mutlak). Sama halnya teori Pembalasan (retribution).

Jauh sebelum teori ini muncul, seorang filsuf Inggris, Francis Bacon (1561-1626) telah moneat lex, priusquam feriat artinya: undang-undang harus memberikan peringatan terlebih dahulu sebelum merealisasikan ancaman yang terkandung di dalamnya. ${ }^{15}$ Dengan demikian, asas legalitas menghendaki bahwa ketentuan yang memuat perbuatan dilarang harus dituliskan terlebih dahulu.

Dalam tradisi civil law system, ada empat aspek asas legalitas yang diterapkan secara ketat, yaitu: peraturan perundang-undangan (law), retroaktivitas (retroactivity), lex certa, dan analogi. ${ }^{16}$ Mengenai keempat aspek ini, menurut Roelof $\mathrm{H}$. Haveman, though it might be said that not every aspect is that strong on its own, the combination of the four aspects gives a more true meaning to principle of legality. ${ }^{17}$ Ke-empat aspek asas legalitas di atas penjelasannya sebagai berikut:

1. Lex Scripta: tertulis

Dalam civil law system, aspek pertama adalah pemidanaan harus didasarkan pada undang-undang, dengan kata lain berdasarkan hukum yang tertulis. Undang-undang (statutory, law) harus mengatur mengenai tingkah laku (perbuatan) yang dianggap sebagai tindak pidana. Tanpa undangundang yang mengatur mengenai perbuatan yang dilarang, maka perbuatan tersebut tidak bisa dikatakan sebagai tindak pidana. Hal ini berimplikasi bahwa hukum kebiasaan/hukum yang hidup tidak bisa dijadikan dasar menghukum seseorang. Tidak bisanya kebiasaan menjadi dasar penghukuman bukan berarti kebiasaan tersebut tidak mempunyai peran dalam hukum pidana. Ia menjadi penting dalam menafsirkan element of crimes yang terkandung dalam tindak pidana yang dirumuskan oleh undangundang tersebut. ${ }^{18}$

2. Lex Certa: Jelas dan rinci

Dalam kaitannya dengan hukum yang tertulis, pembuat undangundang (legislatif) harus merumuskan secara jelas dan rinci mengenai perbuatan yang disebut dengan tindak pidana (kejahatan, crimes). Hal inilah yang disebut dengan asas lex certa atau bestimmtheitsgebot. Pembuat

${ }^{14}$ Moeljatno, Asas - Asas Hukum Pidana, Rineka Cipta, Jakarta, 2008, hlm. 27

15 Ibid, hlm. 355.

${ }^{16}$ Muchamad Iksan, Asas Legalitas Dalam Hukum Pidana : Studi Komparatif Asas Legalitas Hukum Pidana Indonesia Dan Hukum Pidana Islam (Jinayah), Jurnal Serambi Hukum Vol. 11 No. 01 Februari - Juli , FH-Universitas Muhammadiyah Surakarta (UMS),2017 hlm 8

17 Ibid

${ }^{18}$ ELSAM, , Asas Legalitas KUHP Dalam Rancangan 2005, Posistion Paper Advokasi RUU KUHP Seri 1, Jakarta, 2005, hlm. 6-7. 
PRESUMPTION of LAW

Fakultas Hukum Universitas Majalengka

Volume 3 Nomor 1 April 2021

undang-undang harus mendefinisikan dengan jelas tanpa samar-samar (nullum crimen sine lege stricta), sehingga tidak ada perumusan yang ambigu mengenai perbuatan yang dilarang dan diberikan sanksi. Perumusan yang tidak jelas atau terlalu rumit hanya akan memunculkan ketidakpastian hukum dan menghalangi keberhasilan upaya penuntutan (pidana) karena warga selalu akan dapat membela diri bahwa ketentuanketentuan seperti itu tidak berguna sebagai pedoman perilaku. ${ }^{19}$ Namun demikian ELSAM ${ }^{20}$ berpendapat, dalam prakteknya tidak selamanya pembuat undang-undang dapat memenuhi persyaratan di atas. Tidak jarang perumusan undangundang diterjemahkan lebih lanjut oleh kebiasaan yang berlaku di dalam masyarakat apabila norma tersebut secara faktual dipermasalahkan

3. Analogi

Analogi artinya memperluas berlakunya suatu peraturan dengan mengabstraksikannya menjadi aturan hukum yang menjadi dasar dari peraturan itu (ratio legis) dan kemudian menerapkan aturan yang bersifat umum ini kepada perbuatan konkrit yang tidak diatur dalam undangundang.

Penerapan peraturan secara analogi ini dilakukan apabila ada kekosongan (leemte ata lucke) dalam undangundang untuk perbuatan (peristiwa) yang mirip dengan apa yang diatur oleh undang-undang. Akan tetapi sebaliknya apabila ada peristiwa (baru) yang tidak diatur dalam undang-undang maka peraturan itu tidak diterapkan, apabila tidak sesuai dengan rasio dari peraturan tersebut. Penggunaan yang demikian itu disebut argumentum a contrario (pemberian alasan secara dibalik/bewijs van het tegendeel). ${ }^{21}$

Seperti disebutkan di muka, asas legalitas membatasi secara rinci dan cermat tindakan apa saja yang dapat dipidana. Namun demikian, dalam penerapannya, ilmu hukum memberi peluang untuk dilakukan interpretasi terhadap rumusan-rumusan perbuatan yang dilarang tersebut. Dalam ilmu hukum pidana dikenal beberapa metode atau cara penafsiran, yaitu: penafsiran tata bahasa atau gramatikal, penafsiran logis, penafsiran sistematis, penafsiran historis, penafsiran teleologis atau sosiologis, penafsiran kebalikan, penafsiran membatasi, penafsiran memperluas, dan penafsiran analogi. ${ }^{22}$

Dari sekian banyak metode penafsiran tersebut, penafsiran analogi telah menimbulkan perdebatan di antara para yuris yang terbagi ke dalam dua kubu, menerima dan menentang penafsiran analogi. Secara ringkas, penafsiran analogi adalah apabila terhadap suatu perbuatan yang pada saat

${ }^{19}$ Jan Remmelink, Hukum Pidana: Komentar Atas PasalPasal Terpenting dari Kitab Undang-Undang Hukum Pidana Belanda dan Padanannya dalam Kitab Undang-undang Hukum Pidana Indonesia, PT Gramedia Pustaka Utama, Jakarta, 2003, hlm. 358.

${ }^{20}$ ELSAM, Loc-Cit.

21 Sudarto, Hukum Pidana I, Cetakan ke-dua, Yayasan Sudarto Fakultas Hukum UNDIP, semarang 1990,hlm. 22-23.

${ }^{22}$ Sofyan Sastrawidjaja, Hukum Pidana: Asas Hukum Pidana Sampai pada Peniadaan Pidana, Armica, Bandung, 1995, hlm. 68-72. 
PRESUMPTION Of LAW

Fakultas Hukum Universitas Majalengka

Volume 3 Nomor 1 April 2021

dilakukannya tidak merupakan tindak pidana, diterapkan ketentuan hukum pidana yang berlaku untuk tindak pidana lain yang mempunyai sifat atau bentuk yang sama dengan perbuatan tersebut, sehingga kedua perbuatan tersebut dipandang analog satu dengan lainnya.

Menurut Andi Hamzah ${ }^{23}$, ada dua macam analogi, yaitu: gesetz analogi dan recht analogi. Gesetz analogi adalah analogi terhadap perbuatan yang sama sekali tidak terdapat dalam ketentuan pidana. Sementara recht analogi adalah analogi terhadap perbuatan yang mempunyai kemiripan dengan perbuatan yang dilarang dalam ketentuan hukum pidana.

Beberapa alasan yang menyetujui dipakainya analogi, di antaranya adalah karena perkembangan masyarakat yang sedemikian cepat sehingga hukum pidana harus berkembang sesuai dengan perkembangan masyarakat itu. Sementara yang menentang mengatakan bahwa penerapan analogi dianggap berbahaya karena dapat menyebabkan ketidakpastian hukum dalam masyarakat. Dalam perkembangannya, pembatasan dan penggunaan analogi ini tergantung pada sistem hukum yang dianut suatu negara.

Menurut Jan Remmelink ${ }^{24}$, inti dari penafsiran analogis, bagi pendukung pendekatan ini tidak membatasi pengertian suatu aturan hanya dalam batas-batas polyseem kata-kata. Bila diperlukan, mereka akan siap sedia mengembangkan dan merumuskan aturan baru (hukum baru), tentu tidak dengan sembarang melainkan dalam kerangka pemikiran, rasio ketentuan yang bersangkutan. Dalam perkembangannya, karena trauma pada saat pemerintahan Nazi, timbul keengganan yang besar terhadap penggunaan metode ini di seluruh Eropa dan Belanda.

4. Non-retroaktif

Asas legalitas dipandang dari ruang berlakunya hukum pidana menurut waktu yang berkaitan dengan non retroaktif menghendaki bahwa ketentuan peraturan perundang-undangan yang merumuskan tindak pidana tidak dapat diberlakukan secara surut (non retroaktif).

Lebih khusus menyangkut asas legalitas, meskipun sering dirujuk dengan adagium berbahasa latin nullum delictum nulla poena sine praevia lege poenali sebagaimana tersebut sebelumnya, Jan Remmelink mengungkapkan bahwa adagium tersebut justru tidak berasal dari hukum Romawi Kuno. Adagium dimaksud dikembangkan oleh juris Jerman yang bernama von Feuerbach sebagai bagian dari ajaran klasik. Dalam bukunya, Lehrbuch des Peinlichen Rechts (1801), Feuerbach mengemukakan teori tekanan jiwa (Psychologische Zwang Theorie) yang menyatakan bahwa suatu ancaman pidana merupakan usaha preventif terjadinya tindak pidana itu sendiri, sehingga diharapkan orang yang akan melakukan tindak pidana mampu menekan niatnya.

\section{E. Metode Penelitian}

Metode penelitian dipergunakan dalam rangka memperoleh kemudian

\footnotetext{
${ }^{23}$ Andi Hamzah, Asas-Asas Hukum Pidana, Rineka Cipta, Jakarta, 2008, hlm. 44

${ }^{24}$ Jan Remmelink, Op.Cit., hlm. 359
} 
PRESUMPTION Of LAW

Fakultas Hukum Universitas Majalengka

Volume 3 Nomor 1 April 2021

menganalisis setiap informasi yang bersifat ilmiah dan tentunya dibutuhkan pula suatu metode dengan tujuan agar suatu karya ilmiah itu memiliki susunan yang sistematis, terarah dan konsisten. ${ }^{25}$ Penelitian ini adalah penelitian hukum dengan pertimbangan bahwa titik tolak penelitian adalah mengkaji Asas Legalitas. Pendekatan yang digunakan dalam penelitian adalah pendekatan filsafat (philosophy approach), pendekatan undang-undang (statue approach), pendekatan sejarah (historys approach). Bahan hukum yang digunakan dalam penelitian ini disesuaikan adalah:

1. Bahan hukum primer, yaitu bahan hukum yang mengikat dan terdiri dari norma dasar yaitu Undang-Undang Dasar Negara Republik Indonesia Tahun 1945, Kitab Undang-Undang Hukum Pidana (KUHP), UndangUndang Republik Indonesia Nomor 8 Tahun 1981 tentang Kitab Undangundang Hukum Acara Pidana (KUHAP), Undang-Undang Nomor 48 Tahun 2009 tentang Kekuasaan Kehakiman. Undang-Undang Nomor 16 Tahun 2004 tentang Kejaksaan Republik Indonesia. RUU KUHP tahun 2019,

2. Bahan hukum sekunder, yaitu bahan-bahan yang memberi penjelasan mengenai sumber data primer seperti, rancangan undang-undang, yurisprudensi, hasil seminar, makalah-makalah, jurnal, majalah hukum dan naskah lain yang mempunyai relevansi dengan objek yang diteliti

3. Bahan hukum tertier, yaitu bahan hukum yang memberikan petunjuk maupun penjelasan terhadap bahan hukum primer, dan sekunder. Contohnya website, ensiklopedia, kamus. ${ }^{26}$

Guna lebih mempermudah pembahasan, maka informasi yang didapat dan diperoleh selanjutnya dihimpun melalui proses yang bertahap. Berawal dari sumber-sumber yang tertulis yang berasal dari peraturan perundangundangan dan tulisan-tulisan lain yang berhubungan dengan inti permasalahan. Selanjutnya bahan-bahan hukum yang sudah berhasil dikumpulkan diolah sesuai dengan keperluan untuk dijadikan bahan pembahasan dengan jalan menghimpun dan mengklasifikasikannya dalam masing-masing bab dan sub bab yang telah disusun berurutan menurut pokok permasalahan untuk kemudian dianalisis.

Bahan-bahan hukum yang sudah dikumpulkan tersebut dianalisis dengan berpedoman pada metode kualitatif, yaitu suatu cara penelitian yang menghasilkan informasi deskriptif analitis, dan terkumpul untuk kemudian menguraikan fakta yang telah ada dalam jurnal ini kemudian ditarik suatu kesimpulan dan saran dengan memanfaatkan cara berpikir deduktif yaitu menarik kesimpulan yang berangkat dari hal-hal yang bersifat umum menuju hal-hal yang bersifat khusus.

\section{F. Hasil Penelitian dan Pembahasan}

\section{Kedudukan Asas Legalitas Dalam Hukum Pidana Indonesia}

Asas legalitas merupakan salah satu asas yang fundamental dalam

${ }^{25}$ Soerjono Soekanto \& Sri Mamudji, Penelitian Hukum Normatif: Suatu Tinjauan Singkat, Rajawali Press, Jakarta, 1990, hlm. 1.

${ }^{26}$ Ibid 
PRESUMPTION of LAW

Fakultas Hukum Universitas Majalengka

Volume 3 Nomor 1 April 2021

hukum pidana Indonesia. Selain asas ini terdapat asas lainnya yaitu asas culpabilitas. Peranan kedua asas tersebut adalah menentukan suatu perbuatan dapat dijatuhi pidana atau tidak. Khususnya menentukan titik awal ada atau tidaknya suatu perbuatan pidana pada pelaku yang sekaligus menentukan pertanggungjawabannya.

Keberadaan asas legalitas berkaitan dengan perkembangan kehidupan bernegara yang berhubungan dengan kedudukan hukum dalam negara. Pada awalnya hukum pidana bersumber dari hukum tidak tertulis. Pada zaman Romawi kuno sebagian besar hukum pidana bersifat tidak tertulis. Abad pertengahan saat hukum Romawi Kuno diterima di Eropa Barat, terdapat perbuatan "crimine extra ordinaria" atau "kejahatan yang tidak disebutkan dalam undang-undang", yang diterima oleh para raja yang berkuasa. Oleh karena tidak terdapat dalam undang-undang, maka raja yang berkuasa bertindak sewenang-wenang dengan kekuasaan yang dimilikinya secara absolut. Masyarakat atau warga tidak dapat mengetahui secara pasti tentang perbuatan mana yang dilarang dan perbuatan mana yang tidak dilarang. ${ }^{27}$

Dampak dari kesewenang-wenangan raja, maka rakyat menuntut adanya kepastian hukum (legal certainty). Pemikiran antitese kesewenangwenangan raja disebut sebagai zaman Aufklarung. Pada kondisi tersebut muncul para pemikir diantaranya Beccaria. Pendapat Beccaria adalah: ${ }^{28}$

"Undang-undang pidana itu dibentuk berdasarkan asas-asas yang bersifat lebih rasional yaitu yang di satu pihak dapat membatasi hakhak penguasa untuk menjatuhkan hukuman-hukuman, berdasarkan pemikiran bahwa kebebasan pribadi para warga negara itu sejauh mungkin harus dihormati yaitu terutama dalam undang-undang pidana, suatu ketentuan pidana yang telah ada terlebih dahulu harus merupakan suatu syarat mutlak untuk dipakai sebagai dasar bagi hakim dalam menjatuhkan suatu hukuman, dan di lain pihak dapat menyelesaikan pertumbuhan hukum pidana sebagai hukum publik"

Pengaruh pemikiran Beccaria diimplementasikan dalam Code Penal Prancis Tahun 1791. Walaupun Code Penal ini tidak berlangsung lama berlakunya, namun pendapat Beccaria tersebut merupakan pemikiran awal bagi terbentuknya asas legalitas yang tercantum dalam Pasal 4 Code Penal Prancis yang baru dan Wetboek van Strafrecht Belanda yang sekarang Pasal 1 ayat (1 ) KUHP. Pasal 4 Code Penal Prancis berkaitan juga dengan Pasal 8 dari Declaration Des Droits De L'homme Et Du Citoyen.

Selain Beccaria, pemikiran yang melandasi asas legalitas berasal dari Jean Jacques Rousseau dalam bukunya yang berjudul "Du contrat social, ou principes du droit politigue", yang menyatakan ${ }^{29}$ :

27 Warih Anjari, Kedudukan Asas Legalitas Pasca Putusan Mahkamah Konstitusi Nomor 003/PUU-IV/2006 dan 025/PUU-XIV/2016, Jurnal Konstitusi, Fakultas Hukum Universitas 17 Agustus 1945 Volume 16, Nomor 1, Maret 2019, Jakarta, hlm 7

${ }^{29}$ Ibid 
PRESUMPTION of LAW

Fakultas Hukum Universitas Majalengka

Volume 3 Nomor 1 April 2021

"Seluruh hukum bersumber pada suatu contrat social yang kemudian telah diserahkan kepada volunte generale untuk mengaturnya lebih lanjut. Akan tetapi jenis-jenis tindakan yang oleh volunte generale telah dikaitkan dengan akibat yang berupa hukuman bagi pelanggarnya itu wajib dicantumkan dalam undang-undang. Oleh karena itu dalam perikatan kemasyarakatan tersebut, setiap orang hanyalah menyerahkan sebagian kecil saja dari kebebasankebebasannya."

Pandangan yang berkaitan dengan asas legalitas lainnya dikemukakan oleh Montesquie, yang menyatakan: "Dalam pemerintahan yang moderat hakim harus berkedudukan terpisah dari penguasa dan harus memberikan hukuman setepat mungkin sesuai ketentuan harfiah hukum. Hakim harus bertindak hati-hati untuk menghindari tuduhan tidak adil terhadap orangorang yang tidak bersalah". ${ }^{30}$

Mendasarkan pada sejarah terbentuknya asas legalitas maka tujuannya adalah adanya kepastian hukum tentang perbuatan mana yang dipidana dan perbuatan mana yang tidak dipidana. Dengan kepastian hukum tersebut maka akan dapat mencegah kesewenang-wenangan penguasa untuk menetapkan pemidanaan kepada pelaku tindak pidana.

Asas legalitas berbunyi "Nullum crimen nulla poena sine praevia lege poenali" yang dibuat oleh Paul Johann Anselm Von Feurbach. Dalam ilmu pengetahuan hukum pidana dikenal dengan ajaran"leer van de psychologische dwang" atau "ajaran pemaksaan psikologis". Menurut Anselm Von Feurbach:

"Tujuan utama dari hukum pidana adalah memaksa penduduk secara psikologis agar jangan sampai mereka melakukan tindakan yang melanggar hukum. Pemaksaan secara psikologis tersebut dapat dilakukan dengan cara memberikan ancaman-ancaman hukuman bagi mereka yang ternyata telah melakukan pelanggaran dan dengan cara menjatuhkan hukuman-hukuman kepada para pelanggarnya. Asas ini dibentuk untuk kepentingan umum dan untuk menjamin hak-hak semua warga masyarakat secara lebih baik dan bukan sebagai pengakuan terhadap invidualisme".

Berdasarkan pendapat tersebut, maka penjatuhan pidana yang dilakukan oleh hakim harus tercantum dalam undang-undang sehingga merupakan akibat dari adanya ketentuan pidana dalam perundang-undangan.

Asas legalitas berkaitan erat dengan aliran pemikiran positivisme hukum. Positivisme hukum menyatakan bahwa hukum identik dengan undang-undang, yang diluar undang-undang bukan merupakan hukum. Hukum harus dipisahkan dari moral, politik, budaya, ekonomi, dan lainlainnya. Pandangan positivisme hukum terkait dengan pemikiran filsafat

30 Eddy O.S Hiariej, Asas Legalitas \& Penemuan Hukum Dalam Hukum Pidana, Erlangga, Jakarta, 2002, hlm. 9 
PRESUMPTION of LAW

Fakultas Hukum Universitas Majalengka

Volume 3 Nomor 1 April 2021

positivisme yang menyatakan bahwa segala sesuatu dianggap benar apabila ia sungguh-sungguh dapat dipastikan sebagai kenyataan ${ }^{31}$. Dalam positivisme hukum harus ada pemisahan yang tegas antara hukum dan moral.

Bertitik tolak dari uraian di atas, pengaruh pemikiran positivisme ke dalam positivisme hukum adalah pertama, dalam hukum terdapat hubungan sebab dan akibat, sehingga hukuman yang dijatuhkan kepada pelaku merupakan akibat dari adanya sebab adanya undang-undang. Inilah asas legalitas dalam hukum pidana. Kedua, aturan hukum merupakan sesuatu yang ada, sedangkan yang tidak ada bukan hukum tetapi moral. ${ }^{32}$

Kelemahan dari positivisme hukum adalah dalam mengidentifikasikan hukum hanya berupa undang-undang. Dalam pengelolaan kekuasaan negara dapat menjadi otoritarian negara, karena: pertama, hanya undang-undang yang menjadi wujud pelaksanaan kekuasaan negara dengan mengesampingkan proses terbentuknya hukum dan penerapan hukum. Kedua, hukum dibentuk secara serta merta dan keberlakuannya atas dasar paksaan negara, ketiga pembuatan hukum dikuasai oleh negara dan penafsirannya untuk kepentingan negara .

Paham yang bertentangan positivisme hukum terdapat adalah sosiological yurisprudence. Menurut pandangan ini hukum yang baik adalah sesuai dengan hukum yang hidup di masyarakat (the living law). Pemikiran ini berkembang di Indonesia dan Amerika. ${ }^{33}$ Hukum adat atau kebiasaan yang beragam di Indonesia merupakan salah satu pendukung berkembangnya aliran ini. Dukungan secara normatif ada dalam Pasal 5 ayat (1) Undang-Undang No. 48 Tahun 2009 tentang Kekuasaan Kehakiman, dimana hakim dan hakim konstitusi wajib menggali, mengikuti, dan memahami nilai-nilai hukum dan keadilan yang hidup di masyarakat. Demikian pula Pasal 10 ayat (1) Undang-Undang No. 48 Tahun 2009 tentang Kekuasaan Kehakiman yang intinya menyatakan pengadilan dilarang menolak untuk memeriksa perkara yang diajukan dengan dalih hukumnya tidak ada, melainkan wajib memeriksa dan mengadilinya. Legalitas penerapan hukum kebiasaan dalam hukum pidana terdapat dalam Pasal 5 ayat (3) sub b Undang-Undang No. 1 Tahun 1951 tentang TindakanTindakan Sementara Untuk Menyelenggarakan Kesatuan, Susunan, Kekuasaan dan Acara Pengadilan Sipil.

Berkaitan dengan legal culture, adalah pendapat dari Werner Menski tentang triangular concept of legal pluralism yang menonjolkan karakter plural kultur dan hukum. Hukum yang plural berkaitan dengan keanekagaraman hukum positif, sistem hukum, sistem peradilan, dan hlm. 106 .

${ }^{31}$ Sukarno Aburaera, dkk., Filsafat Hukum Teori dan Praktek, Kencana, Jakarta, 2013,

${ }^{32}$ Yakub Adi Krisanto, "Penelitian Hukum: Tolak Tarik Antara Positivisme Hukum dan Empirisme Hukum", Jurnal Refleksi Hukum, FH Universitas Kristen Satya Wacana, Edisi April, Jakarta 2008, hlm. 69.

${ }^{33}$ Zainuddin Ali, Filsafat Hukum, Sinar Grafika, Jakarta, 2014,hlm. 61. 
PRESUMPTION of LAW

Fakultas Hukum Universitas Majalengka

Volume 3 Nomor 1 April 2021

perilaku hukum masing-masing individu atau kelompok. Oleh karena bersifat plural maka pendekatan yang dilakukan dapat beragam. Demikian juga Indonesia, tiap daerah memiliki sistem hukum adat yang beragam. Di samping itu, Indonesia juga menghadapi dampak globalisasi terhadap hukum. Sangat tidak relevan jika pendekatan yang dilakukan bersifat positif maupun sosiologis atau empiris saja. Sehingga dibutuhkan pendekatan normatif, empiris, dan filosofis. Pendekatan ini digunakan dalam triangular concept of legal pluralism.

Menurut Werner Menski, terdapat tiga komponen utama dalam hukum yaitu nilai etis, norma-norma sosial, dan aturan yang dibuat oleh negara. Tipe hukum ideal adalah suatu hukum yang menjalin interaksi diantara tiga komponen tersebut secara harmonis. Model yang dikemukakan oleh Menski tersebut di atas, jika dibandingkan dengan negara hukum Pancasila yang demokratis terdapat kesamaan. Konsep negara hukum Pancasila memiliki karakteristik: mengakui asas negara hukum umumnya, yaitu: adanya perlindungan terhadap hak asasi manusia, peradilan yang bebas dan tidak memihak, adanya penerapan asas legalitas; dan prinsip-prinsip lainnya, yaitu: hubungan antara pemerintah dan rakyat berdasarkan asas kerukunan, hubungan fungsional yang proposional antara kekuasaan-kekuasaan negara, penyelesaian sengketa melalui musyawarah dan peradilan merupakan sarana terakhir, serta keseimbangan antara hak dan kewajiban. Ciri- ciri negara hukum Pancasila yang merupakan ciri khas Indonesia: a. Hubungan yang erat antara agama dan negara; b. Bertumpu pada Ke-Tuhanan yang Maha Esa; c. Kebebasan beragama dalam arti positif; c. Ateisme tidak dibenarkan; e. Komunisme dilarang; f. Asas kerukunan dan kekeluargaan. ${ }^{34}$ Dalam karakteristik negara hukum Pancasila, adanya pengakuan negara hukum umumnya merupakan aturan yang dibuat oleh negara (state made rules). Sedangkan ciri lainnya merupakan ethic values dan social norms.

Asas legalitas dalam hukum pidana positif di Indonesia tercantum dalam Pasal 1 ayat (1 ) KUHP. KUHP berlaku sejak tahun 1946 berdasarkan asas konkordansi. Namun berdasarkan Undang-Undang Darurat No. 1 Tahun 1951 Pasal 5 ayat (3) sub b menyatakan perbuatan menurut hukum yang hidup harus dianggap delik sepanjang tiada bandingnya dalam KUHP, hakim dapat menjatuhkan pidana penjara maksimum 3 (tiga) bulan bagi tindak pidana dimaksud. Aturan tersebut hingga sekarang digunakan oleh hakim untuk menjatuhkan pidana terhadap tindak pidana kesusilaan. Demikian pula Konsep KUHP 2015 mengintrodusir hukum kebiasaan sebagai dasar pemidanaan dan sanksi adat. Pengaturannya terdapat dalam Pasal 2, Pasal 68 ayat (1) huruf e dan Pasal 68 ayat (3). Sejak tahun 1951 hingga sekarang asas legalitas diterapkan tidak murni dimana terdapat penerapan hukum kebiasaan sebagai dasar pemidanaan atas dasar UndangUndang Darurat No 1 Tahun 1951 yang dikembangkan dalam

${ }^{34}$ M Hendra Wijaya, "Karakteristik Konsep Negara Hukum Pancasila”, FH Unmas, Jurnal Advokasi Vol.5, No. 2 September, Denpasar, 2015, hlm. 212. 
PRESUMPTION of LAW

Fakultas Hukum Universitas Majalengka

Volume 3 Nomor 1 April 2021

yurisprudensi.

Secara teoritis asas legalitas terdiri dari dari dua jenis, yaitu: pertama, asas legalitas formal menetapkan dasar untuk menentukan suatu perbuatan bersifat melawan hukum atau tindak pidana sehingga dapat dipidananya adalah ketentuan yang terdapat dalam undang-undang yang harus ada sebelum perbuatan itu dilakukan. Kedua, asas legalitas material menetapkan bahwa dasar untuk menentukan perbuatan bersifat melawan hukum atau suatu tindak pidana adalah nilai-nilai yang hidup di masyarakat (hukum kebiasaan). ${ }^{35}$ Asas legalitas formal secara tertulis telah diatur dalam Pasal 1 ayat (1) KUHP, sedangkan asas legalitas material terdapat dalam nilai-nilai agama, moral, adat, dan sebagainya, yang tumbuh dan berkembang dalam masyarakat (hukum tidak tertulis). Oleh karena asas legalitas material merupakan nilai-nilai yang hidup di masyarakat maka menjadi refleksi dari keinginan dan rasa keadilan masyarakat, serta memberikan kepastian hukum secara materiial atau substansiil. Sedangkan asas legalitas formal memberikan kepastian hukum secara formil.

Penerapan asas legalitas berdasarkan KUHP merupakan suatu dilemma, karena keberadaan hukum adat yang masih hidup yang tidak mungkin dikodifikasikan seluruhnya; dan harus adanya kepastian hukum dan perlindungan terhadap hak asasi manusia dari perlakuan yang tidak adil dan tidak wajar dari penguasa dan hakim. Bagi yang kontra asas legalitas menyatakan asas legalitas kurang melindungi kepentingan kolektif, karena memungkinkannya dibebaskannya pelaku perbuatan yang pada dasarnya merupakan perbuatan yang merugikan tapi tidak dirumuskan dalam undangundang. Sehingga konsep yang ada dalam asas legalitas adalah perbuatan dianggap tindak pidana karena undang-undang atau peraturan menyatakan sebagai kejahatan dan dipidana (mala qua prohibita), bukan suatu perbuatan dianggap kejahatan karena perbuatan tersebut buruk atau tercela (mala per se). kedudukan Asas legalitas formil diterapkan untuk mencegah kesewenang-wenangan penguasa terhadap orang yang tidak bersalah. Sedangkan asas legalitas materiil untuk mengakomodir hukum tidak tertulis yang masih berlaku di masyarakat.

\section{Konsep Dekonstruksi Asas Legalitas Dalam Hukum Pidana Nasional}

Dekonstruksi asas legalitas dalam hukum pidana dilakukan dengan menggali dan memasukkan nilai-nilai hukum adat agar mampu menyelesaikan penyimpangan kejahatan. ${ }^{36}$ Penyimpangan kejahatan dalam artian bukan tergantung pada ketetapan hukum yang ditetapkan dalam hukum pidana secara tertulis, namun menekankan pula pada hukum tidak tertulis.

Metode dekonstruksi mengenai asas legalitas bahwa yang menjadi pegangan utama para hakim untuk mengkualifikasikan perbuatan pidana

35 Tongat, Dasar-Dasar Hukum Pidana Indonesia dalam Perspektif Pembaharuan, UMM, Malang, 2008, hlm. 51.

${ }^{36}$ Deni Setyo Bagus Yuherawan, Dekonstruksi Asas ...Op.Cit, hlm. 232 
PRESUMPTION of LAW

Fakultas Hukum Universitas Majalengka

Volume 3 Nomor 1 April 2021

diluar yang telah diatur oleh undang-undang pidana adalah hukum pidana tidak tertulis terutama prinsip-prinsip hukum umum. Jika tidak menemukan dasar dalam asas hukum, yang digunakan adalah konsep nilai-nilai moral. Karena hakikat hukum adalah moralitas dan moral merupakan substansi dasar hukum. Maka dari itu hakim harus senantiasa berusaha membentuk hukum atau menguji hukum berdasarkan nilai-nilai moralitas tertinggi, seperti keadilan dan kebenaran.

Dekonstruksi asas legalitas dalam pembaharuan hukum pidana nasional, dikarenakan asas legalitas yang pada akhirnya, memperlihatkan sudah lama ditinggalkannya pemberlakuan asas legalitas secara absolut dalam praktik pengadilan, terlebih dalam konteks hukum pidana Internasional. Bahkan bila dihubungkan dengan penafsiran dan analogi, terbukti bahwa larangan analogi dalam penerapan hukum pidana sebagai konsekuensi asas legalitas seringkali dilanggar oleh hakim pidana dalam rangka tuntutan keadilan dan uraian mengenai penemuan hukum dalam hukum pidana menunjukkan bahwa asas legalitas tidak lagi berpegang pada undang-undang semata, tetapi merujuk pada hukum yang tidak tertulis. ${ }^{3}$

Berdasarkan hasil re-eksaminasi derajat asas legalitas sulit dipertahankan dan sudah waktunya dilakukan dekonstruksi terhadap asas legalitas untuk kemudian membangun asas hukum lain yang lebih komprehensif dibandingkan asas legalitas. Berdasarkan rumusan asas tersebut, sumber hukum pidana adalah hukum tertulis yakni undang-undang pidana, hukum tidak tertulis yang meliputi hukum kebiasaan atau yang biasa disebut hukum pidana adat serta prinsip-prinsip hukum yang diakui oleh bangsa-bangsa beradab atau masyarakat bangsa-bangsa.

Dekonstruksi asas legalitas dalam pembaharuan hukum pidana diantaranya dapat dilakukan dengan cara sebagai berikut:

a. Kritik ideologis dan dasar kefilsafatan asas legalitas

Asas hukum merupakan resultan pemikiran filsafati tentang hukum dan perannya dalam masyarakat serta asas hukum dibangun melalui refleksi yang sangat panjang serta membutuhkan waktu yang lama. Asas hukum dibangun tidak saja untuk mengoreksi tatanan hukum yang sudah tidak sesuai dengan perasaan keadilan masyarakat namun juga untuk membentuk tatanan hukum yang lebih berkeadilan ataupun yang sesuai tuntutan perkembangan zaman.

Asas hukum pada umumnya merupakan perwujudan pergulatan kepentingan, kebutuhan, dan aspirasi masyarakat. Asas hukum tumbuh silih berganti seiring perubahan zaman sehingga dapat dikatakan bahwa asas hukum merupakan anak zaman yang bersangkutan.

Dari perspektif faktor-faktor penyebab munculnya asas hukum serta kondisi obyektif masyarakat, walaupun asas hukum dimaksudkan berlaku secara universal dan dalam waktu yang relatif lama haruslah tetap disadari bahwa asas hukum mempunyai keterbatasan dalam

${ }^{37}$ Nursalam, Dekonstruksi Asas Legalitas Dalam Pembaharuan Hukum Pidana Dan Hukum Islam,Skripsi, Fakultas Syariah Dan Hukum Uin Alauddin Makassar 2016, hlm 53 
PRESUMPTION of LAW

Fakultas Hukum Universitas Majalengka

Volume 3 Nomor 1 April 2021

perspektif tempat dan waktu. Asas legalitas sebagaimana asas hukum yang lain bukan saja hasil pengembanan para filsuf dan ahli hukum pidana untuk menjawab permasalahan hukum dan keadilan melainkan juga sebagai koreksi atau reaksi terhadap sistem peradilan pidana.

Gagasan dasar tentang asas legalitas sudah jauh sebelum terjadinya Revolusi Perancis (1789) yang dianggap sebagai titik kulminasi munculnya asas legalitas. Gagasan dasar asas legalitas merupakan resultan pemikiran filsafati yang merupakan refleksi tentang perlindungan hak-hak individual warga negara dari kekuasaan penguasa yang sewenang-wenang. Untuk memperoleh pemahaman yang komprehensif, sudah seharusnya menganalisis asas legalitas secara kritis dalam perspektif tempat dan waktu.

b. Nullum Crimen Sine Poena sebagai landasan pemidanaan terhadap kejahatan dan perlindungan korban.

Dewasa ini, kita ketahui bahwa tujuan hukum pidana pada umumnya adalah untuk melindungi kepentingan orang perseorangan atau hak-hak asasi manusia dan melindungi kepentingan-kepentingan masyarakat dan negara dengan perimbangan serasi dari kejahatan atau tindakan tercela disatu pihak dan dari tindakan penguasa yang sewenangwenang di lain pihak.8 Akan tetapi, mengenai persoalan dan perwujudan tujuan hukum pidana tersebut dalam sejarahnya telah mengalami proses yang lama dan lambat.

Korban mendapatkan nilai manfaat dari asas legalitas sebatas pada terjadinya mala prohibita. Itu pun jika penguasa benar-benar melakukan penuntutan terhadap pelaku dan korban justru dirugikan dengan eksistensi asas legalitas jika yang dilakukan merupakan criminal extra ordinaria yang mana untuk dan atas nama asas legalitas, penguasa dilarang melakukan penuntutan.

Uraian di atas semakin menegaskan tentang keterbatasan asas legalitas dalam hal ketidakmampuan melakukan penuntutan terhadap pelaku yang melakukan crimina extra ordinaria serta ketidakmampuan melindungi kepentingan korban dalam hal terjadinya crimina extra ordinaria. Sudah saatnya untuk melakukan reeksaminasi terhadap asas legalitas sebagai dasar pemidanaan dan sudah saatnya pula untuk mulai mengintrodusir prinsip nullum crimen sine poena sebagai dasar pemidanaan terhadap kejahatan. Prinsip nullum crimen sine poena secara esensial menegaskan bahwa kejahatan harus dipidana karena asas legalitas yang secara ontologis hanya berisikan undang-undang pidana hanya dapat menuntut mala prohibita. Secara esensial, nullum crimen sine poena legali mempunyai daya jangkau dan ruang lingkup lebih sempit dibandingkan gagasan nullum crimen sine poena.

Daya jangkau nullum crimen sine poena legali hanya terhadap mala prohibita sedang daya jangkau nullum crimen sine poena meliputi mala prohibita dan crimina extra ordinaria. Secara hakiki nullum crimen sine poena legali merupakan bagian dari nullum crimen sine poena. 
PRESUMPTION of LAW

Fakultas Hukum Universitas Majalengka

Volume 3 Nomor 1 April 2021

c. Perimbangan perlindungan terhadap kepentingan pelaku dan kepentingan korban

Sifat hakiki kodrati hak asasi manusia adalah yang melekat pada diri setiap orang tidak dapat dicabut atau dihapuskan oleh siapapun termasuk penguasa negara. ${ }^{38}$ Hal yang paling penting untuk di analisis adalah keterkaitan gradasi kepentingan individual pelaku dengan kepentingan individual korban serta kepentingan sosial masyarakat dengan eksistensi asas legalitas. Sebagaimana telah dijelaskan dalam hal terjadinya crimina extra ordinaria, asas legalitas hanya melakukan fungsi perlindungan terhadap kepentingan pelaku, tapi sama sekali tidak melakukan fungsi perlindungan terhadap korban, baik korban individual dan masyarakat. Asas legalitas sama sekali tidak di orientasikan kepada kepentingan korban, baik korban individual dan masyarakat.

Asas legalitas sama sekali tidak diorentasikan kepada kepentingan korban dan kepentingan korban dan kepentingan sosial dikorbankan demi kepentingan pelaku. Dari perspektif gradasi kepentingan dalam kehidupan masyarakat, asas legalitas tidak selaras dengan kehidupan masyarakat karena asas legalitas telah mengorbankan kepentingan yang lebih utama yakni kepentingan individuindividu lain dan masyarakat. Asas legalitas bertentangan dengan landasan ontologis masyarakat yaitu sosialitas manusia. Selain itu, asas legalitas bertentangan dengan esensi individu dan masyarakat karena hanya melindungi individu pelaku secara esensial hanyalah koeksistensi yang lebih rendah gradasinya dibandingkan dengan kehidupan masyarakat, atau setidaknya sederajat dengan individu korban.

Dari perspektif gradasi kepentingan, sudah saatnya untuk melakukan reeksaminasi terhadap asas legalitas. Suatu asas hukum seharusnya ditujukan untuk melindungi kepentingan yang lebih utama yaitu kepentingan individu-individu lain (korban) dan masyarakat. Dalam konteks yang lebih luas, hukum pidana seharusnya ditujukan untuk melindungi masyarakat termasuk korban di dalamnya karena tujuan dari hukum pidana adalah memperbaiki atau merehabitasi penjahat menjadi orang baik dan berguna bagi masyarakat. Maka dari itu, masyarakat akan memperoleh keuntungan dan tiada seorang pun yang merugi jika penjahat menjadi baik

d. Perimbangan hak konsep, hak untuk tidak dapat dituntut atas dasar hukum yang berlaku surut.

Dengan memahami esensi hak, maka akan menjadi jelas bagaimana seharusnya perimbangan hak dalam kehidupan masyarakat. Sebagaimana diketahui bahwa tujuan terbentuknya suatu masyarakat paling tidak adalah:

1). Memberikan perlindungan terhadap individu dan kelompok dari ancaman dan gangguan oleh individu dan kelompok yang lain.

${ }^{38}$ Ruslan Renggong, Hukum Acara Pidana "Memahami Perlindungan HAM dalam Proses Penahanan di Indonesia Pranada Media Group, Jakarta,2014, hlm. 1 
PRESUMPTION of LAW Fakultas Hukum Universitas Majalengka

Volume 3 Nomor 1 April 2021

2). Mengintegrasikan segala kepentingan baik antar individu, individu dan kelompok maupun antar kelompok sehingga terjadi keserasian dan keseimbangan berbagai kepentingan.

Dalam keadaan seperti inilah norma hukum memainkan peranan penting sebagai sarana perlindungan kepentingan individu dan masyarakat serta hukum diharapkan mampu mengintegrasikan kepentingan dan mencegah serta menyelesaikan segala konflik kepentingan yang ada. Hukum dapat di identikkan dengan hak dan kewajiban dikarenakan secara substansi, hukum memang mememberikan hak dan kewajiban kepada manusia. ${ }^{39}$ Manusia menurut kodratnya memiliki hak dan kewajiban atas sesuatu dalam menjalani kehidupan sosialnya dengan manusia lain. Seseorang tidak boleh menggunakan haknya secara bebas sehingga menimbulkan kerugian atau rasa tidak enak pada orang lain. Maka dari itu, penulis memberikan masukan dari pemaparan tersebut di atas bahwa setiap perbuatan yang dilakukan dengan sengaja sehingga menimbulkan rasa sakit atau penderitaan yang luar biasa baik fisik maupun mental yang ditimbulkan oleh atau atas dorongan atau persetujuan pejabat publik atau orang yang bertindak dalam kedudukan resmi untuk tujuan memperoleh keterangan atau pengakuan dari orang yang disiksa itu atau dari orang ketiga dengan menghukum orang yang karena suatu tindakan yang telah dilakukan disangka telah dilakukannya atau dengan menekan orang tersebut dengan orang lain.

e. Kewenangan mengkualifikasikan perbuatan pidana bukanlah monopoli kekuasaan legislatif.

Paradoks-paradoks antara idealita hukum dengan realitas sosial yang banyak terjadi dalam masyarakat dewasa ini menuntut keruntutan pembenahan sistem penegakan hukum dan kejelasan rancang bangun identitas dan kerangka asas hukum nasional dari para arsitek bangunan hukum yang komprehensif yang tidak sekedar hasil otak-atik para tukang-tukang beraliran legalitas formal sehingga negara hukum hanya sebagai negara undang-undang saja. Untuk mengantisifasi perkembangan ragam perbuatan pidana yang semakin meningkat secara kuantitas dan kualitas di masa mendatang dengan gagasan yang menyatakan bahwa hanya lembaga legislatif yang berwenang mengkualifikasikan perbuatan pidana harus di evaluasi kembali. Pemikiran harus adanya kekuasaan yudikatif yang mempunyai kewenangan mengkualifikasikan perbuatan pidana merupakan sesuatu yang proporsional terutama dalam perspektif mengantisifasi munculnya criminal extra ordinaria yang tidak segera mungkin di kualifikasikan sebagai mala prohibita oleh undang-undang pidana.

f. Undang-undang pidana hanya salah satu sumber hukum pidana Asas kesatu dari Pasal 1 ayat (1) KUHP. Pasal tersebut hanya

${ }^{39}$ Rahman Syamsuddin dan Ismail Aris, Merajut Hukum di Indonesia, Mitra Wacana Media, Jakarta, 2014, hlm. 33 
PRESUMPTION of LAW

Fakultas Hukum Universitas Majalengka

Volume 3 Nomor 1 April 2021

menentukan bahwa sanksi pidananya harus ditentukan dengan Undangundang. Norma-normanya mengikuti sistem dalam bidang hukum masing-masing, yaitu hukum perdata, hukum tata negara, dan hukum tata usaha negara yang memberikan peranan sepenuhnya kepada adat kebiasaan dan peraturan-peraturan lain yang bukan undang-undang seperti peraturan pemerintah, peraturan menteri, peraturan jawaban, dan macam instruksi dalam dinas administrasi.

Kepustakaan senantiasa menyatakan bahwa sumber hukum dalam civil law system berupa perundang-undangan, kebiasaan, dan jurisprudensi. Yang menjadi rujukan pertama adalah peraturan perundang-undangan, dan berikutnya adalah (hukum) kebiasaan, demikian pendapat Peter Mahmud Marzuki. Pendapat yang sama dikemukakan Satjipto Rahardjo yang menyatakan bahwa perundangundangan merupakan sumber yang bersifat hukum yang paling utama dan sumber berikutnya adalah kebiasaan. ${ }^{40}$

Berdasarkan pendapat 2 (dua) ahli hukum tersebut, maka sumber hukum bukan hanya undang-undang tetapi selain undang-undang terdapat hukum kebiasaan. Tanpa mengurangi eksistensi dan fungsi sumber hukum yang lain dalam analisis terhadap eksistensi fungsi undang-undang dan hukum kebiasaan menunjukkan betapa hukum kebiasaan dalam sejarah perkembangan hukum pidana pernah menjadi sumber hukum utama.

g. Esensi substansial undang-undang pidana bukanlah kehendak dan perintah penguasa.

Soejono Soekanto berpendapat bahwa pergaulan hidup manusia diatur oleh berbagai macam aturan atau norma yang pada hakikatnya bertujuan menghasilkan kehidupan bersama yang tertib dan tentram. ${ }^{41}$ Kehidupan sosial yang dibangun di atas berbagai kepentingan dan kebutuhan melahirkan aturan yang mengatur simpang siur kepentingan dan kebutuhan manusia yakni aturan yang disepakati diterapkan untuk memperoleh ketertiban dan keamanan manusia dalam hubungan dengan sesamanya. Semakin terbiasa dengan aturan yang berlaku maka terbentuklah adat.

Gagasan pokok asas legalitas adalah penggunaan undang-undang pidana sebagai instrumen untuk membatasi keabsolutan kekuasaan penguasa dan kewenangan hakim. Undang-undang pidana merupakan satu-satunya instrumen untuk mengkualifikasikan perbuatan pidana. sebagaimana telah di uraikan bahwa keharusan dengan undang-undang pidana untuk mengkualifikasikan perbuatan pidana secara awal di gagas oleh John Locke yang kemudian di artikulasikan paling tidak oleh Mountesquieu, Rousseu, dan Beccaria.

Gagasan tentang keharusan dengan undang-undang pidana untuk mengkualifikasikan perbuatan pidana menjadi sumber inspirasi bagi

\footnotetext{
${ }^{40}$ Deni Setyo Bagus Yuherawan, Dekonstruksi Asas ..Op.Cit hlm. 232

${ }^{41}$ Beni Ahmad Saebani, Sosiologi Hukum, Pustaka Setia, Bandung, 2006, hlm. 146
} 
PRESUMPTION of LAW

Fakultas Hukum Universitas Majalengka

Volume 3 Nomor 1 April 2021

Mountesquieu, Rousseau, dan Beccaria. Orientasi keharusan dengan undang-undang dalam pemikiran ketiga pemikir ini mengalami perubahan orientasi meskipun esensinya tetap sama yaitu sebagai perwujudan perlindungan hak-hak individu dan pembatasan kekuasaan penguasa termasuk hakim.

h. The revival of natural law sebagai upaya mencapai keadilan.

Suatu krisis masyarakat mempunyai pengaruh yang lebih besar terhadap hukum daripada terhadap lain-lain aktivitas sosial dan perubahan dalam dasar-dasar masyarakat mengubah pula dasar-dasar nilai hukum. Dasar-dasar hukum dengan jelas dipengaruhi oleh dasar politik, ekonomi, kehidupan sosial, kesusilaan, sebaliknya hukum mempunyai tugas memberi kepadanya bentuk dan ketertiban.

Pokok pikiran the revival of natural law dapat digunakan untuk melakukan reekasaminasi terhadap asas legalitas. Asas legalitas yang ditopang oleh positivisme hukum hanya mengakui undang-undang sebagai satu satunya sumber hukum dengan memisahkan undang-undang dari ide-ide tentang moralitas. The revival of natural law mengajarkan bahwa moralitas merupakan unsur regulatif dan konstitutif sekaligus norma etis dan evaluatif terhadap undang-undang serta mengajarkan moralitas merupakan aspek substansial dari undang-undang. Undangundang yang tidak bersubstansikan moralitas tidak layak dinamakan hukum. Hukum yang sungguh-sungguh merupakan hukum adalah hukum yang merupakan perwujudan nilai-nilai moral dan ditujukan untuk mencapai keadilan.

i. Rumusan asas hukum lain sebagai dasar pemidanaan terhadap perbuatan pidana.

Dalam hal ini perlu dikemukakan dan dikembangkan asas hukum, patut dipidananya perbuatan pidana dengan rumusan "setiap kejahatan atau perbuatan pidana harus dipidana jika bertentangan dengan hukum pidana baik tertulis maupun tidak tertulis" atau dapat juga dengan rumusan nullum delictum nulla poena sine praevea iure poenali (tiada perbuatan pidana, tiada pidana, tanpa hukum pidana).

Berdasarkan rumusan asas tersebut, sumber hukum pidana adalah hukum tertulis yakni undang-undang pidana dan hukum tidak tertulis yang meliputi hukum kebiasaan termasuk hukum pidana adat serta prinsip-prinsip hukum umum yang diakui oleh bangsa-bangsa beradab atau masyarakat bangsa-bangsa. Dengan sumber hukum yang seperti ini akan mampu didayahgunakan untuk menuntut mala prohibita maupun crimina extra ordinaria. Dengan dituntutnya crimina extra ordinaria, asas hukum ini secara praksis melakukan fungsi perlindungan terhadap korban.

j. Keberlakuan asas legalitas di Indonesia di masa mendatang

Apa yang selama ini di terima sebagai sesuatu yang benar harus mulai kita pertanyakan kembali terhadap teori hukum, asas hukum, atau ajaran-ajaran yang selalu mengedapankan ide keteraturan yang jelas pasti 
PRESUMPTION of LAW

Fakultas Hukum Universitas Majalengka

Volume 3 Nomor 1 April 2021

yang selama ini menghuni alam pikiran liberal atau positivist hukum mulai di gugat karena ternyata ide tersebut tidak mampu memberikan penjelasan yang terjadi selama ini sepanjang perjalanan hukum Indonesia yang terus dilanda krisis. Adanya berbagai penerobosan terhadap asas legalitas baik dalam tataran aturan hukum maupun praktik hukum terlebih lagi penerobosan juga dilakukan melalui Rancangan Undangundang (RUU) sampai Kitab Undang-undang Hukum Pidana (KUHP) sudah saatnya untuk tidak memberlakukan asas legalitas secara absolut. Di masa mendatang dengan tidak memberlakukan asas legalitas secara absolut maka crimina extra ordinaria terutama yang menimbulkan kerugian luar biasa bagi korban atau masyarakat yang dapat dituntut. Selama re-eksaminasi tidak ditujukan terhadap kelemahan landasan ontologis dan aksiologis asas legalitas dengan segala keterbatasannya juga tidak dilakukan dari titik anjak internal maka masih akan menempatkan asas legalitas sebagai kebenaran yang harus dijunjung tinggi dan tidak menggoyahkan derajat asas legalitas. Sudah saatnya pula melakukan dekonstruksi terhadap asas legalitas bahwa asas legalitas tidak cukup untuk digunakan sebagai dasar untuk melakukan penuntutan perbuatan-perbuatan pidana terutama di masa mendatang yang mana perbuatan-perbuatan pidana akan semakin sophisticated akibat perkembangan teknologi informasi dan komunikasi sehingga belum atau tidak di kualifikasikan sebagai mala prohibita oleh suatu undang-undang pidana. Asas legalitas tidak cukup untuk digunakan sebagai dasar untuk melakukan penuntutan perbuatan-perbuatan pidana terutama di masa mendatang yang mana perbuatan-perbuatan pidana akan semakin bertambah. Akhirnya perlu dirumuskan asas hukum lain yang lebih komprehensif dibandingkan asas legalitas. Perlu ditumbuhkembangkan asas patut dipidananya perbuatan pidana dengan rumusan setiap perbuatan pidana harus dipidana jika bertentangan dengan hukum pidana baik tertulis maupun tidak tertulis atau dapat juga dengan rumusan nullum delictum nulla poena sine praevea iure poenali yaitu tiada perbuatan pidana, tiada pidana, tanpa hukum pidana

\section{G. Kesimpulan}

1. Kedudukan Asas legalitas secara formil maupun materiil sangat dibutuhkan dalam penegakan hukum pidana di Indonesia. Asas legalitas formil diterapkan untuk mencegah kesewenang-wenangan penguasa terhadap orang yang tidak bersalah. Sedangkan asas legalitas materiil untuk mengakomodir hukum tidak tertulis yang masih berlaku di masyarakat.

2. Konsep dekonstruksi mengenai asas legalitas bahwa yang menjadi pegangan utama para hakim untuk mengkualifikasikan perbuatan pidana diluar yang telah diatur oleh undang-undang pidana adalah hukum pidana tidak tertulis terutama prinsip-prinsip hukum umum. Jika tidak menemukan dasar dalam asas hukum, yang digunakan adalah konsep nilai-nilai moral. Karena 
PRESUMPTION of LAW Fakultas Hukum Universitas Majalengka

Volume 3 Nomor 1 April 2021

hakikat hukum adalah moralitas dan moral merupakan substansi dasar hukum.

\section{H. Saran}

1. Bagi lembaga legislatif agar dapat mengkaji dan menganalisa asas legalitas, hal ini mengingat eksistensi asas legalitas dan hukum kebiasaan yang samasama dibutuhkan dalam penegakan hukum pidana maka diperlukan suatu model asas legalitas yang dapat mengakomodir keduanya

2. Bagi para penegak hukum terutama hakim, harus senantiasa berusaha membentuk hukum atau menguji hukum berdasarkan nilai-nilai moralitas tertinggi, seperti keadilan dan kebenaran. 


\section{DAFTAR PUSTAKA}

\section{A. Buku :}

Andi Hamzah, Asas-Asas Hukum Pidana, Rineka Cipta, Jakarta, 2008.

Barda Nawawi Arief, Beberapa Aspek penegakan dan Pengembangan Hukum Pidana, PT. Citra Aditya Bakti, Bandung:2011.

Beni Ahmad Saebani, Sosiologi Hukum, Pustaka Setia, Bandung, 2006.

Deddy Ismatullah, Ilmu Negara dalam Multi Perspektif Kekuasaan, Masyarakat, Hukum, dan Agama, Pustaka setia, Bandung, 2007.

Deni Setyo Bagus Yuherawan, Dekonstruksi Asas Legalitas Hukum Pidana; Sejarah Asas Legalitas dan gagasan Pembaharuan Filosofis Hukum Pidana, Setara Press, Malang.2014

Eddy O.S Hiariej, Asas Legalitas \& Penemuan Hukum Dalam Hukum Pidana, Erlangga, Jakarta, 2002,

Jan Remmelink, Hukum Pidana: Komentar Atas PasalPasal Terpenting dari Kitab Undang-Undang Hukum Pidana Belanda dan Padanannya dalam Kitab Undang-undang Hukum Pidana Indonesia, PT Gramedia Pustaka Utama, Jakarta, 2003.

Moeljatno, Asas - Asas Hukum Pidana, Rineka Cipta, Jakarta, 2008.

Moeljatno, Asas-Asas Hukum Pidana, Rineka Cipta, Jakarta, 2000.

Rahman Syamsuddin dan Ismail Aris, Merajut Hukum di Indonesia, Mitra Wacana Media, Jakarta, 2014.

Ruslan Renggong, Hukum Acara Pidana "Memahami Perlindungan HAM dalam Proses Penahanan di Indonesia Pranada Media Group, Jakarta,2014,

Soerjono Soekanto \& Sri Mamudji, Penelitian Hukum Normatif: Suatu Tinjauan Singkat, Rajawali Press, Jakarta, 1990.

Sofyan Sastrawidjaja, Hukum Pidana: Asas Hukum Pidana Sampai pada Peniadaan Pidana, Armica, Bandung, 1995.

Sudarto, Hukum Pidana I, Cetakan ke-dua, Yayasan Sudarto Fakultas Hukum UNDIP, semarang 1990.

Sukarno Aburaera, dkk., Filsafat Hukum Teori dan Praktek, Kencana, Jakarta, 2013, 
PRESUMPTION of LAW Fakultas Hukum Universitas Majalengka

Volume 3 Nomor 1 April 2021

Tongat, Dasar-Dasar Hukum Pidana Indonesia dalam Perspektif Pembaharuan, UMM Press, Malang. 2012.

Tongat, Dasar-Dasar Hukum Pidana Indonesia dalam Perspektif Pembaharuan, UMM, Malang, 2008,

Zainuddin Ali, Filsafat Hukum, Sinar Grafika, Jakarta, 2014,

\section{B. Peraturan Perundang-undangan}

Undang-Undang Dasar Negara Republik Indonesia Tahun 1945,

Kitab Undang-Undang Hukum Pidana (KUHP),

Undang-Undang Republik Indonesia Nomor 8 Tahun 1981 tentang Kitab

Undang-undang Hukum Acara Pidana (KUHAP),

Undang-Undang Nomor 48 Tahun 2009 tentang Kekuasaan Kehakiman.

Undang-Undang Nomor 16 Tahun 2004 tentang Kejaksaan Republik

Indonesia. RUU KUHP tahun 2019,

\section{Sumber Lain:}

\section{Jurnal dan Makalah}

Deni SB Yuherawan, Kritik Ideologis Terhadap Dasar Kefilsafatan Asas Legalitas Dalam Hukum Pidana, Jurnal Dinamika Hukum Vol. 12 No. 2 Mei 2012.

ELSAM, Asas Legalitas KUHP Dalam Rancangan 2005, Posistion Paper Advokasi RUU KUHP Seri 1, Jakarta. 2005,

I Dewa Made Suartha, "Pergeseran Asas Legalitas Formal Ke Formal dan Material, Dalam Pembaharuan Hukum Pidana Nasional, Fakultas Hukum Universitas Udayana Yustisia. Vol. 4 No. 1 Januari - April 2015 .

M Hendra Wijaya, "Karakteristik Konsep Negara Hukum Pancasila", FH Unmas, Jurnal Advokasi Vol.5, No. 2 September, Denpasar, 2015,

Muchamad Iksan, Asas Legalitas Dalam Hukum Pidana : Studi Komparatif Asas Legalitas Hukum Pidana Indonesia Dan Hukum Pidana Islam (Jinayah), Jurnal Serambi Hukum Vol. 11 No. 01 Februari - Juli, FHUniversitas Muhammadiyah Surakarta (UMS),2017

Nursalam, Dekonstruksi Asas Legalitas Dalam Pembaharuan Hukum Pidana Dan Hukum Islam,Skripsi, Fakultas Syariah Dan Hukum Uin Alauddin Makassar 2016,

Warih Anjari, Kedudukan Asas Legalitas Pasca Putusan Mahkamah Konstitusi Nomor 003/PUU-IV/2006 dan 025/PUU-XIV/2016, Jurnal Konstitusi, Fakultas Hukum Universitas 17 Agustus 1945 Volume 16, Nomor 1, Maret, Jakarta. 2019, 
PRESUMPTION of LAW Fakultas Hukum Universitas Majalengka

Volume 3 Nomor 1 April 2021

Yakub Adi Krisanto, "Penelitian Hukum: Tolak Tarik Antara Positivisme Hukum dan Empirisme Hukum", Jurnal Refleksi Hukum, FH Universitas Kristen Satya Wacana, Edisi April, Jakarta 2008, 